\title{
Elevated levels of vasoactive intestinal peptide in the eye and urinary bladder of diabetic and prediabetic Chinese hamsters
}

\author{
A.R. Diani ${ }^{1}$, T.Peterson ${ }^{1}$, G. A.Sawada ${ }^{1}$, B. M. Wyse ${ }^{1}$, M.C. Blanks ${ }^{1}$, G. C. Gerritsen ${ }^{1}$, G. Terenghi ${ }^{2}$, I. M. Varndel1 ${ }^{2}$, \\ J.M. Polak ${ }^{2}$, M. A. Blank ${ }^{3}$ and S. R. Bloom ${ }^{3}$ \\ Diabetes and Gastrointestinal Diseases Research ${ }^{1}$, The Upjohn Company, Kalamazoo, Michigan, USA; Departments of Histochemistry ${ }^{2}$ \\ and Medicine ${ }^{3}$, Royal Postgraduate Medical School, Hammersmith Hospital, London, UK
}

\begin{abstract}
Summary. The eyes and urinary bladder of non-diabetic, prediabetic and diabetic Chinese hamsters were evaluated by radioimmunoassay and immunocytochemistry to determine the content and distribution of vasoactive intestinal peptide (VIP). The average concentration of VIP was increased in the eyes of all diabetic $(\mathrm{pmol} / \mathrm{g}=68 \%, \mathrm{pmol} /$ organ $=50 \%)$ and prediabetic $(\mathrm{pmol} / \mathrm{g}=152 \%, \mathrm{pmol} / \mathrm{organ}=115 \%)$ hamsters compared with age-matched non-diabetic animals. Immunocytochemistry showed that the elevation of VIP was primarily related to greater intensity of fluorescence of the nerve fibres in the vasculature of the choroid. The average content of VIP in the urinary bladder was greater in diabetic animals only on the basis of pmol/organ (135\%) and in prediabetics on the ba-
\end{abstract}

sis of pmol/g (87\%) compared with non-diabetic animals. Qualitative immunocytochemistry suggested that the elevated level of VIP was related to a larger distribution of nerve fibres in the urinary bladder of diabetic hamsters. The high level of VIP in the eyes and urinary bladder of diabetic and prediabetic hamsters is an interesting observation which should receive further study to determine whether it is an aetiological agent underlying the pathogenesis of ophthalmic complications and neurogenic bladder or the result of some pathological process which affects these organs.

Key words: VIP, radioimmunoassay, immunocytochemistry, eyes, urinary bladder, prediabetes, diabetic Chinese hamsters.
Complications of the eye and urinary bladder have been documented in patients with diabetes mellitus and most animal models of this disease. With respect to the eye, lesions have been adequately described in the retina [1-5]. Although the specific type of lesion varies among animals and man, the vasculature of the eye is always adversely affected [5]. Several investigations have demonstrated that distension [6-9] and hypertrophy [10] concomitant with urine retention are characteristic of the urinary bladder of diabetic man and animals. Urinary bladder dysfunction is believed to be a product of diabetic autonomic neuropathy $[11,12]$ which promotes impairment of detrusor muscle function $[8,13]$. Although it has recently been disputed [9], a reduction in cholinergic innervation $[7,14]$ has been proposed as a possible mechanism which elicits bladder dysfunction. Despite intensive research, the primary aetiological agent(s) underlying the derangements in the eye and urinary bladder of diabetic man and animals remain under investigation.

Vasoactive intestinal peptide (VIP) has been shown to be present in high quantities in the eye [15-19] and urogenital tract [20-23] of several species, including man. Due to its potent vasodilator activity [24] and its possible involvement in regulation of relaxation [25-27] and contraction [28] of the urogenital tract, it was of interest to determine whether concentration and/or distribution of this peptide are altered in the eye and urinary bladder of a suitable diabetic animal model. Since the spontaneously diabetic Chinese hamster is adequately ics, metabolic characteristics and disorders of the eye and urinary bladder [29], it seemed appropriate to evaluate VIP in this species. Therefore, the purpose of the present study was to determine by radioimmunoassay and immunocytochemistry whether VIP was deranged in the eye and urinary bladder of diabetic and prediabetic XA, AC and AH genetic sublines of Chinese hamsters compared with age-matched non-diabetic $M$ subline animals.

\section{Materials and methods}

\section{Animals}

The Chinese hamsters were selected from The Upjohn Company colony. Prediabetic and diabetic animals of both sexes (ratio three males: two females) were chosen from the $\mathrm{XA}, \mathrm{AC}$ and $\mathrm{AH}$ inbred genetic sublines. Non-diabetic hamsters of both sexes were taken from the $\mathbf{M}$ inbred genetic subline. Definitions, metabolic characteristics and genetic background of prediabetic, diabetic and non-diabetic Chinese hamsters have been described in detail elsewhere [29]. Prediabetic and diabetic animals were age- and sex-matched with the nondiabetic animals. Age of the prediabetic hamsters ranged from 22 to 30 days, whereas that of the diabetic animals varied from 9 to 12 months. Duration of diabetes in the diabetic hamsters spanned 7 to 10 months. All animals were fed Purina mouse breeder chow $(11 \%$ fat) and water ad libitum and housed individually under controlled photoperiod (12 h light/day; lights on at $0600 \mathrm{~h}$ ) and environmental conditions. At termination, blood was drawn from the orbital sinus and non-fasting glucose and $\beta$-hydroxybutyrate (ketones) were measured fluorometrically by an autoanalyzer (Technicon, Tarrytown, New York) [30]. Plasma insulin levels were determined by immunoas- 


\section{Radioimmunoassay of VIP}

Prediabetic hamsters from the XA $(n=5), \mathrm{AC}(n=5)$ and $\mathrm{AH}(n=5)$ inbred sublines and age- and sex-matched non-diabetic animals from the $\mathrm{M}(n=5)$ inbred subline were weighed and then killed by cervical dislocation. An identical number of diabetic and age- and sexmatched non-diabetic hamsters from the same sublines were also terminated. Both eyes and the urinary bladder were resected immediately from each animal. Each pair of eyes and the bladder (minus the urine) were weighed (wet weight) on an analytical balance and frozen on dry ice. Tissues were stored at $-70^{\circ} \mathrm{C}$ until the time of extraction. Each tissue was immersed for $10 \mathrm{~min}$ in boiling $0.5 \mathrm{~mol} / 1$ acetic acid $(10 \mathrm{ml} / \mathrm{g}$ of tissue). The cooled acid extracts were then assayed for their VIP content. The VIP antiserum was used at a final dilution of $1: 320,000$ with reaction to the whole peptide molecule. Under these conditions the assay had a detection limit of $0.4 \mathrm{fmol} /$ assay tube [32]. The VIP levels were calculated as $\mathrm{pmol} / \mathrm{g}$ and $\mathrm{pmol} / \mathrm{organ}$ due to the altered weight of the eyes and/or bladder in the diabetic and prediabetic animals.

Radioactive VIP label was prepared by chloramine $\mathrm{T}$ oxidation [32], followed by high resolution ion exchange chromatography for purification of the monoiodinated VIP. The resulting ${ }^{125}$ I-VIP label had a sp. act. of between 1.6 and $1.0 \mathrm{mCi} / \mathrm{mol}$ and remained stable for up to 3 months at $-20^{\circ} \mathrm{C}$ [32].

\section{Immunocytochemistry of VIP}

An identical number of prediabetic, diabetic and age- and sexmatched non-diabetic hamsters from $\mathrm{XA}, \mathrm{AC}, \mathrm{AH}$ and $\mathrm{M}$ inbred genetic sublines were killed as described under radioimmunoassay. At termination, the eyes and bladder were fixed by immersion in $0.4 \%$ benzoquinone in phosphate buffered saline (PBS; $10 \mathrm{nmol} / 1$; ph 7.1-7.40) at $4^{\circ} \mathrm{C}$ for $45 \mathrm{~min}$ and $95 \mathrm{~min}$, respectively [33]. The fixed tissues were thoroughly rinsed in 7\% sucrose in PBS. Each tissue was mounted on cork and snap frozen in isopentane pre-cooled $\left(-145^{\circ} \mathrm{C}\right)$ in liquid nitrogen. Sections $(15-20 \mu \mathrm{m})$ were cut in a cryostat at $-20^{\circ} \mathrm{C}$, mounted on slides coated with poly-L-lysine [34] and airdried for at least $30 \mathrm{~min}$. Longitudinal sections of the bladder were cut to allow microscopic analysis of the dome and trigone.

Immunocytochemistry was conducted using the indirect immunofluorescence method [35]. Sections were incubated with VIP antiserum (dilution $1: 2000$ ) for $16-20 \mathrm{~h}$ in a moist atmosphere at $4{ }^{\circ} \mathrm{C}$. A second layer of fluorescein-conjugated goat anti-rabbit globulin was applied at a dilution of $1: 150$ for $1 \mathrm{~h}$ at room temperature. Sections were mounted in PBS-glycerine $(1: 9, \mathrm{vol} / \mathrm{vol})$ and examined under a fluorescence microscope by an individual who was not aware of animal identity. The sections were examined to define the distribution of VIP in the eye and bladder and to qualitatively evaluate the level of VIP (intensity of fluorescence) in diabetic and prediabetic compared with non-diabetic hamsters.

Absorption controls, proposed by Sternberger [36], included the use of VIP antiserum which had been incubated previously with excess VIP $(0.1 \mathrm{nmol} / \mathrm{ml}$ of diluted antiserum). Non-immune rabbit serum as a first layer and fluorescein conjugated globulin also served as controls.

\section{VIP antisera}

The VIP antisera for radioimmunoassay and immunocytochemistry were raised in New Zealand white rabbits against natural porcine VIP coupled to bovine serum albumin by the carbodiimide method [32]. The antisera reacted with C-terminal synthetic VIP fragments (but not $\mathrm{N}$-terminal fragments) and showed no cross-reactivity with secretin, glucagon, peptide histidine isoleucine, or gastric inhibitory peptide which are structurally related to VIP or with any of the neuropeptides known to be present in the studied tissues.

\section{Statistics}

The blood glucose, $\beta$-hydroxybutyrate, plasma insulin, body and organ weight and VIP radioimmunoassay data in diabetic and predia-
Table 1. Blood glucose, plasma insulin and plasma $\beta$-hydroxybutyrate in diabetic, pre-diabetic and non-diabetic Chinese hamsters in the radioimmunoassay study

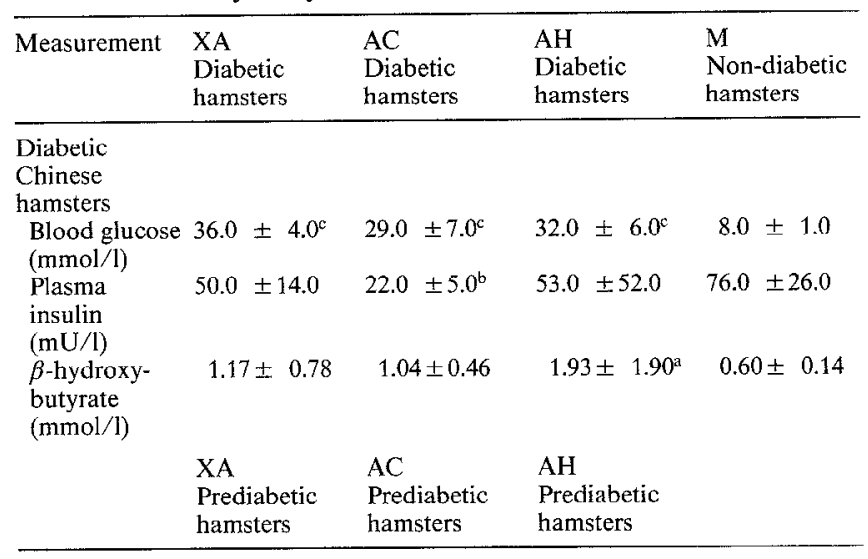

\begin{tabular}{|c|c|c|c|c|}
\hline \multicolumn{5}{|l|}{$\begin{array}{l}\text { Prediabetic } \\
\text { Chinese } \\
\text { hamsters }\end{array}$} \\
\hline $\begin{array}{l}\text { Blood glucose } \\
(\mathrm{mmol} / \mathrm{l})\end{array}$ & $3.0 \pm 2.0$ & $4.0 \pm 1.0$ & $4.0 \pm 1.0$ & $4.0 \pm 1.0$ \\
\hline $\begin{array}{l}\text { Plasma } \\
\text { insulin } \\
(\mathrm{m} \mathrm{U} / 1)\end{array}$ & $48.0 \pm 15.0$ & $27.0 \pm 9.0$ & $57.0 \pm 20.0$ & $34.0 \pm 22.0$ \\
\hline $\begin{array}{l}\beta \text {-hydroxy- } \\
\text { butyrate } \\
\text { (mmol/1) }\end{array}$ & $0.91 \pm 0.24$ & $1.19 \pm 0.16^{b}$ & $0.68 \pm 0.06$ & $0.78 \pm 0.13$ \\
\hline
\end{tabular}

Results cxpressed as mean $\pm \mathrm{SD},\left(n=5\right.$, all groups); ${ }^{\mathrm{a}} p<0.05 ;{ }^{\mathrm{b}} p<0.01 ;{ }^{\mathrm{c}} p<$ $0.001 ; p$ values derived from $M$ versus XA, AC, AH

betic sublines compared with the non-diabetic subline were evaluated by the Student's t-test. Differences were considered to be significant at $p<0.05$ using a two-tailed test. All data are represented as mean \pm $\mathrm{SD}$.

\section{Results}

\section{Radioimmunoassay study of VIP}

The metabolic data of all groups Chinese hamsters are presented in Table 1 . The blood glucose values were significantly elevated in all diabetic compared with the non-diabetic hamsters $(p<0.001)$. The prediabetic and non-diabetic hamsters displayed similar blood glucose levels which were in the euglycaemic range. Plasma insulin was significantly decreased only in the AC diabetic animals $(p<0.01)$. Plasma insulin levels were not altered among prediabetic and non-diabetic hamsters. Plasma $\beta$-hydroxybutyrate was significantly increased in the $\mathrm{AH}$ diabetic $(p<0.05)$ and in the $\mathrm{AC}$ prediabetic animals $(p<0.001)$.

The body and organ weights and VIP levels of the eyes and urinary bladder of the non-diabetic, diabetic and prediabetic Chinese hamsters are shown in Table 2. The body weights were unchanged between diabetic and non-diabetic animals. The body weights of prediabetic XA and AC Chinese hamsters were significantly lower in comparison with the non-diabetic $M$ animals $(p<0.05 ; p<0.01$ respectively). The weight of both eyes was significantly less in diabetic (XA, $p<0.05$; AC, $p<0.05 ; \mathrm{AH}, p<0.001)$ and prediabetic (XA, $p<0.01$; AC, $p<0.001$; AH, $p<0.01)$ animals compared with non-diabetic animals. The weight of the distended uri- 
Table 2. Organ weights and VIP levels of the eyes and bladder of diabetic, pre-diabetic and non-diabetic Chinese hamsters

\begin{tabular}{|c|c|c|c|c|}
\hline Measu & $\begin{array}{l}\text { XA } \\
\text { Diabetic } \\
\text { hamsters }\end{array}$ & $\begin{array}{l}\text { AC } \\
\text { Diabetic } \\
\text { hamsters }\end{array}$ & $\begin{array}{l}\text { AH } \\
\text { Diabetic } \\
\text { hamsters }\end{array}$ & $\begin{array}{l}\mathrm{M} \\
\text { Non-diabetic } \\
\text { hamsters }\end{array}$ \\
\hline \multicolumn{5}{|l|}{$\begin{array}{l}\text { Diabetic } \\
\text { hamsters }\end{array}$} \\
\hline $\begin{array}{l}\text { Body weight } \\
\text { (g) }\end{array}$ & $31 \pm 5$ & $33 \pm 3$ & $30 \pm 4$ & $29 \pm 4$ \\
\hline $\begin{array}{l}\text { Weight of } \\
\text { eyes (mg) }\end{array}$ & $155.4 \pm 9.8^{\mathrm{a}}$ & $155.8 \pm 1.5^{\mathrm{a}}$ & $143.6 \pm 6.6^{c}$ & $169.3 \pm 5.1$ \\
\hline $\begin{array}{l}\text { Weight of } \\
\text { bladder (mg) }\end{array}$ & $54.2 \pm 16.0^{\mathrm{b}}$ & $55.5 \pm 17.0^{b}$ & $59.5 \pm 14.9^{\mathrm{b}}$ & $25.9 \pm 3.1$ \\
\hline $\begin{array}{l}\text { VIP eye } \\
\text { (pmol/g) }\end{array}$ & $6.2 \pm 1.7^{b}$ & $6.2 \pm 1.2^{b}$ & $6.2 \pm 0.7^{\mathrm{b}}$ & $3.7 \pm 1.2$ \\
\hline (pmol/organ) & $0.96 \pm 0.25^{b}$ & $0.94 \pm 0.16^{\mathrm{a}}$ & $0.88 \pm 0.13^{\mathrm{a}}$ & $0.62 \pm 0.18$ \\
\hline \multirow{3}{*}{$\begin{array}{l}\text { VIP bladder } \\
\text { (pmol/g) } \\
\text { (pmol/organ) }\end{array}$} & $10.0 \pm 1.7^{\mathrm{a}}$ & $6.1 \pm 1.4$ & $7.4 \pm 4.4$ & $6.7 \pm 0.6$ \\
\hline & $0.53 \pm 0.11^{\mathrm{c}}$ & $0.33 \pm 0.08^{b}$ & $0.34 \pm 0.07^{\mathrm{b}}$ & $0.17 \pm 0.21$ \\
\hline & $\begin{array}{l}\text { XA } \\
\text { Prediabetic } \\
\text { hamsters } \\
\end{array}$ & $\begin{array}{l}\mathrm{AC} \\
\text { Prediabetic } \\
\text { hamsters }\end{array}$ & $\begin{array}{l}\text { AH } \\
\text { Prediabetic } \\
\text { hamsters }\end{array}$ & \\
\hline \multicolumn{5}{|l|}{$\begin{array}{l}\text { Prediabetic } \\
\text { hamsters }\end{array}$} \\
\hline $\begin{array}{l}\text { Body weight } \\
\text { (g) }\end{array}$ & $13 \pm 1^{a}$ & $12 \pm 1^{\mathrm{b}}$ & $15 \pm 4$ & $16 \pm 1$ \\
\hline $\begin{array}{l}\text { Weight of } \\
\text { eyes (mg) }\end{array}$ & $80.8 \pm 7.3^{b}$ & $76.2 \pm 2.7^{c}$ & $80.0 \pm 5.9^{b}$ & $91.6 \pm 3.3$ \\
\hline $\begin{array}{l}\text { Weight of } \\
\text { bladder (mg) }\end{array}$ & $13.4 \pm 2.1$ & $15.7 \pm 2.0$ & $17.9 \pm 7.7$ & $23.3 \pm 11.5$ \\
\hline $\begin{array}{l}\text { VIP eye } \\
\text { (pmol/g) }\end{array}$ & $12.6 \pm 1.2^{\mathrm{c}}$ & $10.8 \pm 1.5^{\mathrm{c}}$ & $10.0 \pm 2.0^{c}$ & $4.4 \pm 0.1$ \\
\hline & $1.01 \pm 0$ & $2 \pm 0$ & $0.80 \pm 0$ & $0.41 \pm 0.13$ \\
\hline $\begin{array}{l}\text { VIP bladder } \\
(\mathrm{pmol} / \mathrm{g})\end{array}$ & $10.8 \pm 2.4^{\mathrm{c}}$ & $10.0 \pm 2.5^{b}$ & $8.8 \pm 2.1^{\mathrm{a}}$ & $5.3 \pm 2.2$ \\
\hline (pmol/organ) & $0.15 \pm 0.08$ & $0.15 \pm 0.02$ & $0.14 \pm 0.03$ & $0.11 \pm 0.03$ \\
\hline
\end{tabular}

Results expressed as mean $\pm \mathrm{SD},(n=5$, all groups $) ;{ }^{\mathrm{a}} p<0.05 ;{ }^{\mathrm{b}} p<0.01 ;{ }^{\mathrm{c}} p<$ $0.001 ; p$ values derived from $\mathrm{M}$ versus XA, $\mathrm{AC}, \mathrm{AH}$

Table 3. Blood glucose, plasma insulin and plasma beta-hydroxybutyrate of diabetic, pre-diabetic and non-diabetic Chinese hamsters in the immunocytochemical study

\begin{tabular}{lllll}
\hline Measurement & $\begin{array}{l}\text { XA } \\
\text { Diabetic } \\
\text { hamsters }\end{array}$ & $\begin{array}{l}\text { AC } \\
\text { Diabetic } \\
\text { hamsters }\end{array}$ & $\begin{array}{l}\text { AH } \\
\text { Diabetic } \\
\text { hamsters }\end{array}$ & $\begin{array}{l}\text { M } \\
\text { Non-diabetic } \\
\text { hamsters }\end{array}$ \\
\hline $\begin{array}{l}\text { Diabetic } \\
\text { hamsters } \\
\text { Blood glucose } \\
\text { (mmol/1) }\end{array}$ & $34.0 \pm 9.0^{\mathrm{c}}$ & $34.0 \pm 4.0^{\circ}$ & $36.0 \pm 11.0^{\circ}$ & $7.0 \pm 2.0$ \\
$\begin{array}{l}\text { Plasma } \\
\text { insulin } \\
\text { (mU/1) }\end{array}$ & $83.0 \pm 98.0$ & $14.0 \pm 17.0^{\mathrm{b}}$ & $52.0 \pm 7.0$ & $117.0 \pm 43.0$ \\
$\begin{array}{l}\beta \text {-hydroxy- } \\
\text { butyrate } \\
\text { (mmol/1) }\end{array}$ & $1.87 \pm 1.58$ & $1.75 \pm 1.34$ & $2.14 \pm 1.40^{\mathrm{a}}$ & $0.43 \pm 0.11$ \\
& $\mathrm{XA}$ & $\mathrm{AC}$ & $\mathrm{AH}$ & \\
& Prediabetic & $\begin{array}{l}\text { Prediabetic } \\
\text { hamsters }\end{array}$ & $\begin{array}{l}\text { Prediabetic } \\
\text { hamsters }\end{array}$ & \\
\hline $\begin{array}{l}\text { Prediabetic } \\
\text { hamsters } \\
\text { Blood glucose } \\
\text { (mmol/1) }\end{array}$ & $5.0 \pm 2.0^{\mathrm{b}}$ & $4.0 \pm 1.0^{\mathrm{a}}$ & $5.0 \pm 1.0^{\mathrm{a}}$ & $3.0 \pm 1.0$ \\
$\begin{array}{l}\text { Plasma } \\
\text { insulin } \\
\text { (mU/1) }\end{array}$ & $37.0 \pm 26.0$ & $44.0 \pm 19.0$ & $64.0 \pm 38.0^{\mathrm{a}}$ & $28.0 \pm 9.0$ \\
$\begin{array}{l}\beta \text {-hydroxy- } \\
\text { butyratc } \\
\text { (mmol/1) }\end{array}$ & $0.66 \pm 0.14$ & $1.14 \pm 0.26^{\mathrm{c}}$ & $0.72 \pm 0.11$ & $0.61 \pm 0.09$ \\
\hline
\end{tabular}

Results expressed as mean \pm SD ( $n=5$, all groups); ${ }^{\mathrm{a}} p<0.05 ;{ }^{\mathrm{b}} p<0.01 ;{ }^{\mathrm{c}} p<$ $0.001 ; p$ values derived from $M$ versus XA, AC, AH

nary bladders was significantly increased in all diabetic sublines $(p<0.01)$. Bladder weights were unchanged among prediabetic and non-diabetic animals. The concentration of VIP $(\mathrm{pmol} / \mathrm{g})$ was significantly higher in the eyes of all three groups of diabetic $(p<0.01)$ and prediabetic $(p<0.001)$ hamsters in comparison with non-diabetic animals. The content of VIP (pmol/organ) was also significantly greater in the eyes of all sublines of diabetic (XA, $p<0.01 ; \mathrm{AC}, p<0.05 ; \mathrm{AH}, p<0.05$ ) and prediabetic animals $(p<0.001)$. The amount of VIP in the urinary bladder showed a trend toward elevation in most of the diabetic and prediabetic groups of animals. However, statistically significant increases were observed in diabetic sublines only on the basis of pmol/ organ (XA, $p<0.001 ; \mathrm{AC}, p<0.01 ; \mathrm{AH}, p<0.01$ ) and in prediabetic sublines on the basis of $\mathrm{pmol} / \mathrm{g}(\mathrm{XA}$, $p<0.001 ; \mathrm{AC}, p<0.01 ; \mathrm{AH}, p<0.05)$.

\section{Immunocytochemical study of VIP}

The metabolic data of all groups of Chinese hamsters are shown in Table 3. The XA, AC and $\mathrm{AH}$ diabetic hamsters were severely hyperglycaemic in comparison with the $\mathrm{M}$ non-diabetic animals. Although the blood glucose levels of all prediabetic and non-diabetic hamsters were in the euglycaemic range, a slight but significant increase was observed in the prediabetic XA $(p<$ $0.01), \mathrm{AC}(p<0.05)$ and $\mathrm{AH}(p<0.05)$ animals. Plasma insulin was significantly depressed only in the AC diabetic hamsters $(p<0.01)$. Plasma insulin was similar among prediabetic and non-diabetic hamsters. $\beta$-hydroxybutyrate values were significantly elevated in the $\mathrm{AH}$ diabetic $(p<0.05)$ and in the $\mathrm{AC}$ prediabetic animals $(p<0.001)$.

In the eye, weakly stained VIP-immunoreactive fibres were associated with choroidal blood vessels in the non-diabetic animals (Fig. 1A). There was a notable increase in intensity of VIP immunoreactive fibres in the choroidal vasculature of all sublines of age-matched diabetic Chinese hamsters (Fig. 1 B). In prediabetic compared with non-diabetic hamsters, there appeared to be a modest elevation in the intensity of VIP-containing fibres among the choroidal blood vessels.

With respect to the urinary bladder, there was a paucity of VIP-immunoreactive fibres observed in the tissue of the non-diabetic animals (Fig. 2A). In contrast, the distribution of VIP-containing fibres appeared to be greater in the bladder of all diabetic sublines (Fig. 2B). When prediabetic hamsters were compared with nondiabetics, a similar pattern of few VIP-immunoreactive fibres was found in the tissue. There did not appear to be any variation in the distribution of VIP-immunoreactive fibres between the dome and trigone of the bladder in any group.

\section{Discussion}

On the basis of radioimmunoassay, the results of the current study indicate that VIP is markedly increased in the eye of three diabetic sublines of Chinese hamsters. This derangement is significant, since the increased concentration of VIP ( $\mathrm{pmol} / \mathrm{g}$ and $\mathrm{pmol} / \mathrm{organ}$ ) was documented in eyes which weighed less in diabetic compared with non-diabetic animals. With light micro- 

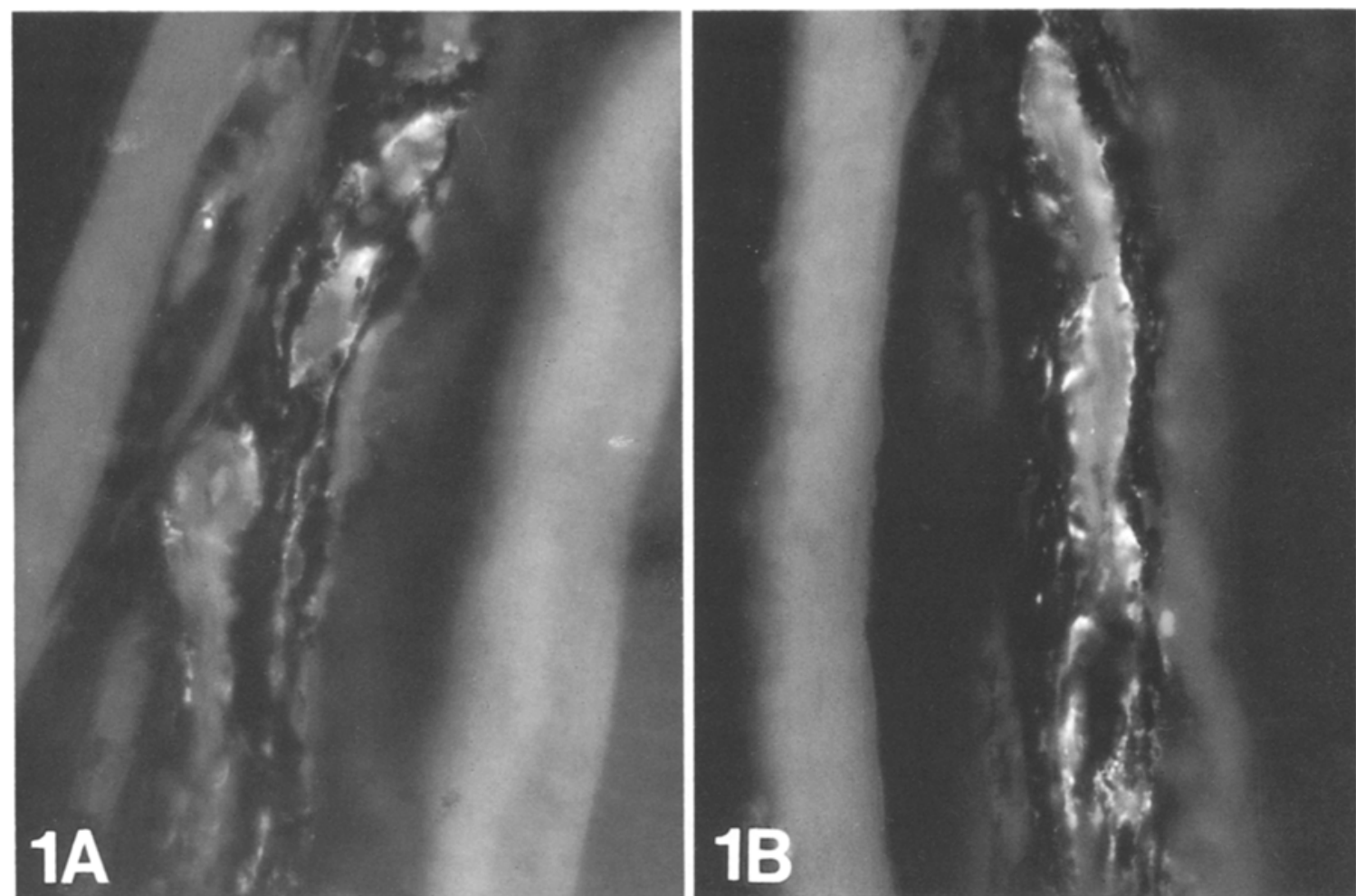

Fig. $1 \mathbf{A}$ and $\mathbf{B}$. In the choroid of non-diabetic animals $\mathbf{A}$ few weakly stained VIP-immunoreactive fibres can be seen around the blood vessels; in diabetic hamsters $\mathbf{B}$ the VIP-immunoreactive fibres display a more intense immunostaining. The sclera is evident on the left side of both figures. Indirect immunofluorescence $(\times 410)$
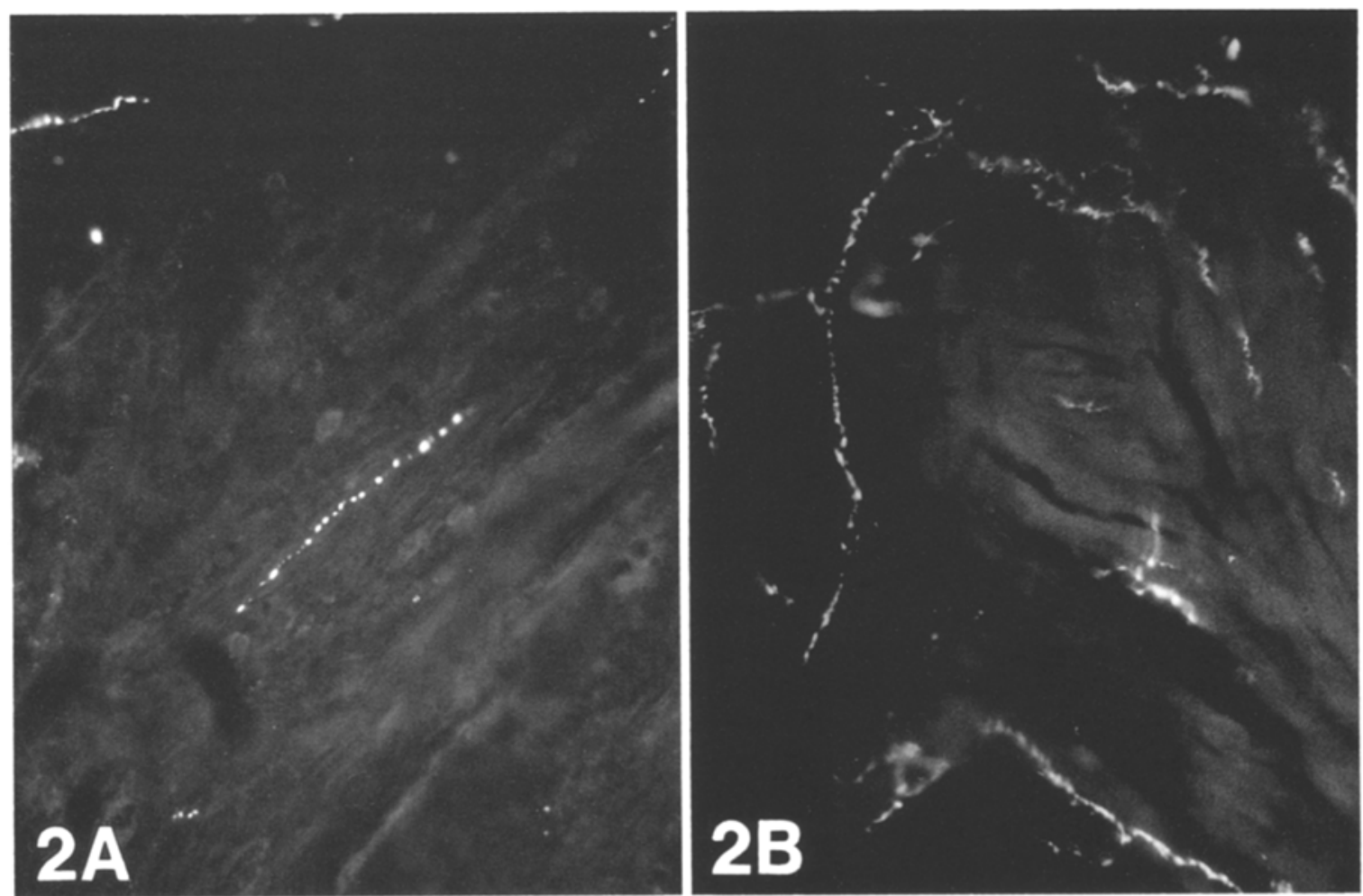

Fig. $2 \mathrm{~A}$ and B. In the bladder, few VIP-immunoreactive fibres are observable in the tissue of non-diabetic animals $\mathbf{A}$ while the immunoreactive fibres appear to be more numerous in diabetic animals B. Indirect immunofluorescence $(\times 290)$ 
scopic immunocytochemistry, the elevation of VIP was confirmed by increased stain intensity of the nerve fibres innervating the choroidal vasculature. The immunocytochemical data suggest that excessive synthesis and/or impaired release of VIP by the choroidal nerve fibres may be an important defect. It has been reported that VIP is a major modulator of blood flow through its activity as a potent vasodilator $[24,37]$. Since the choriocapillaris is known to nourish the visual receptor cells of the retina, it seems feasible that an abnormal vascular blood flow in the choroid may adversely affect these cells in the diabetic Chinese hamster. Although studies of the eye in the spontaneously diabetic Chinese hamster have been restricted to the retina [38-40], it is of interest that the endothelial cell to pericyte ratio was elevated in the retinal capillaries [38]. If a similar numerical alteration occurs among the vascular cells of the choroidal capillaries, it would be important to determine whether high levels of VIP mediate this cellular rearrangement or represent a response to the altered cellular environment. It would also be relevant to establish that chemically-induced diabetes is associated with high VIP levels in the Chinese hamster and in other animals [15-17] which display this peptide in the choroid layer of the eye.

One of the most intriguing findings in the current study was the lower weight of the eyes concomitant with a pronounced elevation of VIP in the choroid of all sublines of prediabetic Chinese hamsters. This early disorder, prior to the onset of hyperglycaemia, implies that an increased concentration of VIP may be a causative factor underlying complications of the eye or a manifestation of some inherent pathological process. It is also possible that the increased concentration of VIP could be a compensatory response in an attempt to increase blood flow and nutrition to the smaller eye. The metabolic and/or genetic parameters, which may promote the rise in VIP in the eye of prediabetic Chinese hamsters, are difficult to define in the current study. Prediabetic Chinese hamsters have been reported to undergo a transient hyperinsulinaemic phase just before the onset of hyperglycaemia [41]. However, the plasma insulin of prediabetic animals as well as other metabolic factors measured in this study, were unchanged. Since the VIP concentration was elevated in the three genetically prediabetic groups, it is conceivable that this alteration may be linked to inheritance factors.

Radioimmunoassay and immunocytochemistry in the present study suggest that organ weight and VIP content (pmol/organ) were increased in the distended bladders of all sublines of diabetic Chinese hamsters. In agreement with a previous study [9], the increase of VIP concentration in the expanded bladder of the diabetic Chinese hamster appears to be meaningful since it can be demonstrated on a pmol/organ basis. This contention is reinforced by the finding of increased acetylcholinesterase activity in the expanded bladder of streptozotocin-diabetic rats [9]. Furthermore, the elevation of VIP in the bladder of the diabetic Chinese hamster may be more meaningful since it has been shown that in- creased weight of the bladder or stretching of the bladder wall under non-diabetic conditions does not induce an automatic increase in choline acetyltransferase activity per organ [42]. With qualitative light microscopic immunocytochemistry, the increase in VIP was related to an increase in the distribution of VIP-ergic fibres in the bladder of diabetic Chinese hamsters. This elevation of VIP immunoreactivity in the bladder of the diabetic Chinese hamster was not observed in the penis of streptozotocin-diabetic rats [23] or diabetic man [23, 43], in which a deficit of VIP-ergic innervation was found. These findings infer that different pathological processes may occur among various species with diabetes or that the derangement of VIP activity is dissimilar in the bladder and penis.

Previous studies have demonstrated that urine retention and enlargement of the urinary bladder were presumably related to a depletion of cholinergic nerves in geriatric, severely diabetic Chinese hamsters [7]. In the current study, VIP derangement was documented in younger, short-term diabetic animals. Therefore, it is logical to hypothesize that an elevation in VIP may be one of the early complications related to bladder dysfunction in the diabetic Chinese hamster. Support for this hypothesis is derived from a previous investigation in which an increase in cholinergic nerve activity was observed in the distended bladders of short-term streptozotocin-diabetic rats [9]. It was also suggested that elevated cholinergic nerve activity in streptozotocin-diabetic rats is probably a compensatory response to allow the hypertrophied detrusor muscle to respond to increased volume and frequency of urine [10]. Since the prediabetic Chinese hamster displayed an elevation of VIP in an unexpanded bladder, it is tempting to speculate that the increase in this peptide is more likely a cause rather than an effect of diabetic cystopathy. The normal physiological role of VIP in the urinary bladder seems to encompass regulation of contraction [28] and/ or relaxation [25-27] of the detrusor muscle. Since a disruption in VIP concentration is associated with bladder distension in the diabetic Chinese hamster, it is conceivable that this abnormality may be detrimental to the function of the smooth musculature.

VIP concentration was higher $(\mathrm{pmol} / \mathrm{g})$ in the bladder of prediabetic compared with age-matched non-diabetic Chinese hamsters. Even though statistical significance on a pmol/organ basis was not obtained, VIP showed a tendency to increase in prediabetes. Unfortunately, the enhanced level of VIP $(\mathrm{pmol} / \mathrm{g})$ in the prediabetic animals could not be verified with immunocytochemistry. This is probably due to the fact that qualitative immunocytochemistry on the light microscopic level is not as sensitive to minor peptide deviations as radioimmunoassay. In any case, the apparent increase in VIP in the bladder of the prediabetic Chinese hamster is an interesting phenomenon which may play an important role in the pathophysiology of diabetic neurogenic bladder. The functional significance of this finding will be the focal point of concerted research in the future. 
Acknowledgement. This study was supported in part by a grant from The Upjohn Company. The authors wish to thank C. Remeur and L. Rogers of The Upjohn Company for typing this manuscript.

\section{References}

1. Patz A, Berkow J, Maumenee A, Cox J (1965) Studies on diabetic retinopathy. II. Retinopathy and nephropathy in spontaneous canine diabetes. Diabetes 11:700-708

2. Kuczurowski M (1970) Angiopathy of retinal vessels in diabetic mice. Arch Ophthalmol (Chicago) 84: 316-320

3. Leuenberger P, Beauchemin ML, Babel J (1974) Experimental diabetic retinopathy. Arch Ophthalmol (Paris) 34: 289-302

4. Engerman R, Bloodworth JM, Nelson S (1977) Relationship of microvascular disease in diabetes to metabolic control. Diabetes 26: 760-769

5. Engerman R, Finkelstein D, Aquirre G, Diddie K, Fox RR, Frank R, Varma SD (1982) Ocular complications. Diabetes 31 (Suppl 1): 82-88

6. Kahan M, Goldberg PD, Mandel EE (1970) Neurogenic vesical dysfunction and diabetes mellitus. NY State J Med 2: 2448-2455

7. Dail W, Evan A, Gerritsen G, Dulin W (1977) Abnormalities in pelvic visceral nerves: a basis for neurogenic bladder in the diabetic Chinese hamster. Invest Urol 15: 161-166

8. Ellenberg M (1980) Development of urinary bladder dysfunction in diabetes mellitus. Ann Intern Med 92: 321-323

9. Lincoln J, Crockett M, Haven AJ, Burnstock G (1984) Rat bladder in the early stages of streptozotocin-induced diabetes: adrenergic and cholinergic innervation. Diabetologia 26: 81-87

10. Lincoln J, Haven AJ, Sawyer M, Burnstock G (1984) The smooth muscle of rat bladder in the early stages of streptozotocin-induced diabetes. Br J Urol 56: 24-30

11. Andersen JT, Bradley WE (1976) Abnormalities of bladder innervation in diabetes mellitus. Urol 7:442-448

12. Buck AC, Reed PI, Siddig YK, Chisholm GD, Fraser TR (1976) Bladder dysfunction and neuropathy in diabetes. Diabetologia 12: $251-258$

13. Buck AC, McRae CU, Reed PI, Chisholm GD (1974) The diabetic bladder. Proc R Soc Med 67: 81-83

14. Faerman I, Glocer L, Celener D, Jadzinsky M, Alvarez E, Fox D, Maler M, Alvarez E (1973) Autonomic nervous system and diabetes: histological and histochemical study of the autonomic nerve fibers of the urinary bladder in diabetic patients. Diabetes 22 : 225-237

15. Uddman R, Alumets J, Ehinger B, Hakanson R, Loren I, Sundler $F(1980)$ Vasoactive intestional peptide nerves in ocular and orbital structures of the cat. Invest Ophthalmol Vis Sci 19: 878-885

16. Unger WG, Butler JM, Cole DF, Bloom SR, McGregor GP (1981) Substance $\mathrm{P}$, vasoactive intestinal polypeptide (VIP) and somatostatin levels in ocular tissue of normal and sensorily denervated rabbit eyes. Exp Eye Res 32: 797-801

17. Terenghi G, Polak JM, Probert L, McGregor CP, Ferri GL, Blank MA, Butler JM, Unger WC, Zhang S, Cole DF, Bloom SK (1982) Mapping, quantitative distribution and origin of substance $\mathrm{P}$ and VIP-containing nerves in the urea of guinea pig eye. Histochemistry $75: 399-417$

18. Tornqvist K, Uddman R, Sundler F, Ehinger B (1982) Somatostatin and VIP neurons in the retina of different species. Histochemistry $76: 137-152$

19. Miller AS, Coster DJ, Costa M, Furness JB (1983) Vasoactive intestinal polypeptide immunoreactive nerve fibers in the human eye. Aust J Ophthalmol 11: 185-193

20. Lynch EM, Wharton J, Bryant MG, Bloom SR, Polak JM, Elder MG (1980) The differential distribution of VIP in the normal human female genital tract. Histochemistry 67: 169-177

21. Alm P, Alumets J, Hakanson R, Owman C, Sjoberg NO, Sundler F, Walles B (1980) Origin and distribution of VIP (vasoactive intestinal polypeptide) nerves in the genito-urinary tract. Cell Tissue Res 205: 337-347

22. Polak JM, Mina S, Gu J, Bloom SR (1981) VIP-ergic nerves in the penis. Lancet 2: 217-219
23. Crowe R, Lincoln J, Blacklay PF, Pryor JP, Lumley JSP, Burnstock G (1983) VIP-like immunoreactive nerves in diabetic penis: a comparison between streptozotocin-treated rats and man. Diabetes 32: 1075-1077

24. Said SI (1984) Vasoactive intestinal peptide (VIP): current status. Peptides 5: 143-150

25. Levin RM, Wein AJ (1981) Effect of vasoactive intestinal peptide on the contractility of the rabbit urinary bladder. Urol Res 9: $217-218$

26. Larsen JJ, Ottesen B, Fahrenkrug J, Fahrenkrug L (1981) Vasoactive intestinal peptide (VIP) in the male genito-urinary tract: concentration and motor effect. Invest Urol 19: 211-213

27. Klarskov P, Gerstenberg T, Hald T (1984) Vasoactive intestinal polypeptide influence on lower urinary tract smooth muscle from human and pig. J Urol 131: 1000-1004

28. Johns A (1979) The effect of vasoactive intestinal polypeptide on the urinary bladder and taenia coli of the guinea pig. Can J Physiol Pharmacol 57: 106-108

29. Gerritsen G (1982) The Chinese hamster as a model for the study of diabetes mellitus. Diabetes 31: 14-21

30. Lloyd B, Burrin J, Smythe P, Alberti KGMM (1978) Enzymatic fluorometric continous-flow assays for blood glucose, lactate, pyruvate, alanine, glycerol and 3-hydroxybutyrate. Clin Chem 24: 1724-1729

31. Blanks MC, Gerritsen GC (1974) An ultra-micro immunoassay for insulin. Proc Soc Exp Biol Med 146: 448-452

32. Mitchell SJ, Bloom SR (1978) Measurement of fasting and postprandial plasma VIP in man. Gut 19: 1043-1048

33. Bishop AE, Polak JM, Bloom SR, Pearse AGE (1978) A new universal technique for the immunocytochemical localization of peptidergic innervation. J Endocrinol 77: 25-26

34. Huang WM, Gibson SJ, Facer P, Gu J, Polak JM (1983) Improved adhesion for immunocytochemistry using high molecular weight polymers of L-lysine as a slide coating. Histochem 77: 275-279

35. Coons AH, Leduc EM, Connolly J (1955) Studies on antibody production: I. A method for the histochemical demonstration of specific antibody and its application to a study of the hyperimmune rat. J Exp Med 102: 49-59

36. Sternberger LA (1974) The unlabelled antibody enzyme method. In: Sternberger LA (ed) Immunocytochemistry. Prentice Hall, New Jersey, pp 129-171

37. Tervo T, Tervo K, Eranko L (1982) Ocular neuropeptides. Med Biol 60: 53-60

38. Federman JL, Gerritsen GC (1970) The retinal vasculature of the Chinese hamster: a preliminary study. Diabetologia 6: 186-191

39. Soret MG, Dulin WE, Gerritsen GC (1973) Microangiopathy in animals with spontaneous diabetes. In: Camerini-Davalos $R$, Cole HS (eds) Early diabetes, advance in metabolic disorders (Suppl 2). Academic Press, New York, pp 291-298

40. Soret MG, Dulin WE, Mathews J, Gerritsen GC (1974) Morphologic abnormalities observed in retina, pancreas and kidney of diabetic Chinese hamsters. Diabetologia 14: 567-579

41. Gerritsen GC, Connell MA, Blanks MC (1981) Effect of environmental factors including nutrition on genetically determined diabetes of Chinese hamsters. Proc Nutr Soc $40: 237-245$

42. Ekstrom $J$ (1981) Increase in choline acetyltransferase activity in surgically isolated postganglionic parasympathetic neurones of the urinary bladder of adult rats. Acta Physiol Scand 111:81-86

43. Gu J, Polak JM, Lazarides M, Morgan R, Pryor JP, Marangos PJ, Blank MA, Bloom SR (1984) Decrease of vasoactive intestinal peptide (VIP) in the penises from impotent men. Lancet 2: 315-317

Received: 16 November 1984

and in revised form: 21 February 1985

Dr. Arthur R. Diani

The Upjohn Company

Diabetes and Gastrointestinal Diseases Research

301 Henrietta Street

Kalamazoo, MI 49001

USA 